\title{
Residential Fires in Metropolitan Areas - Living Conditions and Fire Prevention
}

\begin{abstract}
This chapter addresses the benefits of geo-statistical approaches in fire prevention processes, and especially in the prevention of residential fires in urban areas. The aim is to demonstrate how residential fire incidents can be theorized and placed in a context where geo-statistical techniques and an area-based approach can support the emergency services fire prevention work. The chapter introduces theoretical concepts such as Fire Risk Environment, Fire Protection Capability, as well as determining factors, types of residential fires and various hypotheses for further analysis of residential fires in urban contexts. Key themes are the development of residential fire incidents in different metropolitan areas over time, how different types of residential fires can be connected to living conditions, and finally how the emergency services and other actors can work with area-based fire prevention. Examples from Sweden's major cities and especially the city of Gothenburg are used. The results show that variations in spatial residential fire patterns can be explained by a variation of living conditions. The conditions may also look different depending on the residential area and housing conditions and therefore, preventive strategies and proactive measures should differ between and within cities and be adapted to specific different areas.
\end{abstract}

\section{Introduction}

GIS-based analyses of fire incidents in urban contexts are quite frequent worldwide and in the research literature [1-3]. Different geovisualisation methods are used to clarify patterns of residential fires or other incidents in different metropolitan areas $[4,5]$. Spatial approaches are also applied for theoretical and practical purposes, such as risk modeling, linking fires to socio-economic variables, theorizing and developing hypotheses about the causes of fires, and to analyse different types of fire incidents on various geographical scales within a selected area, e.g. a city, region or nation $[6,7]$. The purposes and approaches of different GIS-based methods vary, but they give valuable input to strategic decisions to rescue services and other related authorities and organizations [8].

The spatial dynamics of residential fires are complex and related to a variety of causes. In order to analyse these causes more thoroughly, different spatial, statistical and theoretical approaches can be applied. An overall challenge is how these ap- 
proaches actually can be combined and develop the analysis of residential fire incidents on different geographic scales. Another important concern is how these approaches can be useful for both researchers and practitioners in a more organized way.

Although GIS-based methods have been applied extensively to study fire incidents, relatively few examples are found in relation to the rescue services' preventive work on residential fires. Some scientific approaches contain spatial and temporal studies of structural fires for prevention of fires in a planning context and fire response [9], the use of GIS to increase understanding of the relationship between fires and the built environment [10], or the investigation of intentional fires and socio-economic conditions as a support for fire prevention measures and fire safety policies [11]. Other related studies includes development and implementation of spatial models to target services based on risks [12,13], the exploration of different spatial methods for rescue services [14], and theoretical approaches to fire prevention and the analysis of spatio-temporal patterns of residential structure fires [15]. In several studies, GIS-based methodologies have been applied and implemented in planning processes in order to mitigate fire risks and improve fire safety [6,16-18]. In this context, geovisualisation is an appropriate visual method for presenting and communicating large datasets and the result of spatial analyses [19,20]. Fire risks or fire incidents are often envisioned through maps, diagrams and figures, where reliability of these visualisations is affected by the quality of data, accumulated errors in the analysis process, and different settings such as used spatial method, scale, bandwidth and choice of visualisation technique [4,5,21].

Thus, there is a need for more comprehensive and validated use of geo-statistical approaches in (residential) fire prevention processes. In this chapter, we aim to demonstrate how residential fire incidents can be theorized and placed in a context where geo-statistical techniques and an area-based approach can support the rescue services fire prevention work. The content of the chapter is based on research and results from a multi-year study on residential fires in metropolitan regions in Sweden [7].

The chapter introduces a theoretical discussion on Fire Risk Environment, Fire Protection Capability, as well as determining factors, types of residential fires and various hypotheses for further analysis of residential fires in urban contexts. Key themes addressed in the chapter are the development of residential fire incidents in different metropolitan areas over time, how different types of residential fires can be connected to living conditions, and finally how the emergency services and other actors can work with area-based fire prevention in metropolitan areas. In the chapter, Sweden's major cities and especially the city of Gothenburg are used as examples. 


\section{Theoretical points of departure}

This section presents the theoretical points of departure of the chapter.

\subsection{Fire Risk Environment and Fire Protection Capability}

Every home and building can be seen as environments where fire can occur. Therefore, the Fire Risk Environment can be defined as the individual, social and technical conditions that affect the probability that a fire incident will occur [22]. People, house types, building structures, technical systems and possible fire sources vary and therefore constitute different types of fire risk environments. Knowledge, intentions, personal characteristics, people's and group's vulnerability or overcrowding in an apartment building can affect the probability of a fire incident. Technical deficiencies or poor maintenance can also lead to technically caused fire incidents. Taken together, the building, the dwelling and the occupants constitute a firerisk environment that can be analysed on the basis of different scales, such as the dwelling/household, the building and the residential area.

Individuals, households and other actors can prevent and manage fire incidents themselves. This can be referred to as Fire Protection Capability. With regard to residential fires, FPC can be defined as the knowledge and ability of individuals, households and other actors to prevent and manage fire incidents in residential buildings [22].

In Sweden, it is unclear how large the proportion of unreported fire incidents in some residential buildings and residential areas are compared to others. Perhaps this difference is because the ability to handle fire incidents in different households differs. Some studies indicate that many residential fire incidents are handled without the intervention of the rescue service. In a study of house fires in the UK and Australia, over $75 \%$ of the fires were self-extinguished or managed by people [23]. In Sweden, it is stated that about 24,000 residential fires occur annually, of which about 6,000 are alerted to the rescue service [24]. Thus, there is an extensive Fire Protection Capability in many households and in the general population $[25,26]$. Differences between residential areas could in that case depend on how well a fire incident is handled. The Fire Protection Capability is normally influenced by different factors, such as individual characteristics and social conditions, socio-technical conditions, and fire conditions [27].

Factors that directly affect the Fire Risk Environment, i.e. the probability of a fire incident may be of a different nature. From an individual and social perspective, fire incidents occurs either through an intentional or unintentional act. Intentional fires are likely to occur due to norm-breaking behavior or mental illness. In the latter case, forgetfulness, inattention, handling defects, cooking mistakes or sleep can lead to fires. Disability, age, addiction, risk behaviors but also how long periods of time 
people stay in their homes are all factors that can affect the probability of a fire. During the ongoing pandemic with covid-19, fire incidents may increase in homes where people residing around the clock and possibly become ill. Social factors can be overcrowding and cooking habits. Technical conditions such as the age of the technology or incorrect installations of electrical or heating systems, as well as poor maintenance, are all examples of technical factors that can affect the probability of fire.

\subsection{Determination factors}

There are several scientific studies and reviews of determining factors for residential fires [11,28-32]. For the most part, various statistical correlation or regression analyses are performed. Often no distinction is made between direct and underlying (indirect) determinants. Common direct determinants that show a connection to fire risks are e.g. mental health, disability, alcohol use, smoking and the proportion of residents who have installed smoke alarms. The underlying determining factors consist of various types of socio-economic data such as unemployment, proportion of people with foreign background, single parents, age, income, proportion of empty residents in an area, but also factors such as the building's technology and construction.

\subsubsection{Direct determination factors}

Based on the definition earlier in this section, the Fire Protection Capability is very much related to the knowledge and abilities that residents and externals have to prevent and manage fire incidents. This knowledge can be of different kinds. It can be declarative, ie. expressed verbally or in symbolic form and be tested. An example is that residents know that smoke alarms are useful and that they should have one. Functional knowledge can be translated into action and is often tested by a person who has learned to solve a concrete problem or a task [33]. To take smoke alarms again as an example, it is about knowing how to set up, replace the battery and test it. Ability is about having the resources to be able to translate declarative and functional knowledge into practical action. If residents do not have access to smoke alarms, tools or the physical ability to set it up and test it, the knowledge does not do much good.

Proactive Fire Protection Capability is about both declarative and functional knowledge and rely on people's ability to assimilate information. Resident's language skills, and their level of education or own and others' experiences can also influence this capability. Reactive Fire Protection Capability is mainly based on 
functional knowledge and ability, ie. how to act when different types of fire incidents occur. Individual characteristics such as disability, age or drug addiction or social conditions such as the number of people in the home are some important factors that affect the reactive Fire Protection Capability. Post-active Fire Protection Capability is about acquiring knowledge and experience of incidents that have occurred and translating this awareness into a proactive action [22].

\subsubsection{Indirect determination factors}

Behind the direct determination factors for residential fires are other elements that have a more indirect impact on fire risk environments and Fire Protection Capability. Below are some important underlying determining factors that can affect people's fire risk environments and the Fire Protection Capability they develop.

Having a job leads to better financial conditions and opportunities to choose type of accommodation and residential area. Unemployment often leads to lower incomes. State and social assistance, financial transfers from others, accumulated reserves of capital and funds can compensate for reduced earned income from work. However, unemployment and reduced income over a longer period usually means limited choices regarding type of housing but also an increased risk of social stress. It can also lead to more time spent in the homes, having more activities there and thus the number of fire incidents may increase.

Education is one of the most central factors behind the opportunities to get a job and thus an economic standard with opportunities to choose the form of accommodation and residential area. A low level of education can in itself, and sometimes-in combination with a migrant background and shortcomings in language skills, lead to difficulties in assimilating various forms of information about fire safety. Despite the fact that basic fire safety is generally well translated from one cultural context to another, there may be differences in knowledge depending on whether residents migrate from an environment where fire safety is more or less applied.

Low income or dependence on income support limits the opportunities to choose housing in the housing market. As indicated above, this factor can be linked to whether residents have jobs or are unemployed. The consequence of low income can be overcrowding and/or that residents are forced to live in homes or residential areas with low or neglected maintenance. Rubbish, damage, and poor cleaning in common areas in apartment buildings can lead to the presence of flammable material in combination with the fact that it signals that no one cares about the residential area.

Overcrowding can increase the probability that a residential fire will occur when cooking, lighting candles, children playing with fire, etc. Homes with many children and adults seem to have a greater fire risk than smaller family units [34]. Overcrowding can also lead to many children and young people staying outside the 
home, but with lower social control and an increased risk of intentional fire setting both indoors and outdoors $[11,35]$.

Age and sex can matter in several ways. Older people, and especially those with various disabilities, may be at greater risk of having a fire, but also of having a poorer Fire Protection Capability in the event of a fire incident. In addition to the very oldest age group, men are strongly overrepresented compared to women when it comes to fatal fires. In general terms of intentional fires in metropolitan areas, it is often a teenage problem where boys and adolescents are overrepresented $[35,36]$.

Single parents, and especially in combination with low incomes and shortcomings in language skills, can give rise to social and economic stress [37]. This in turn can lead to difficulties in maintaining attention, parental authority and setting boundaries for children's behavior.

Various forms of mental and physical illness can lead to more fire incidents at the same time as the ability to detect and manage them is lower. High levels of ill health in a residential area may indicate that there is an overrepresentation of people with risk behaviors regarding fire and thus a reduced Fire Protection Capability.

Being born abroad and moving to a new country can pose major challenges that affect fire protection capabilities. The level of knowledge of the official language of the new country can affect the ability to communicate and assimilate information about fire safety. It also affects the opportunities to acquire knowledge of how to act in the event of a fire, or when a fire develops, and the ability to communicate with others including rescue services. Traditions and habits from the original home country can also affect the Fire Protection Capability. For example, high use of cooking oil or spending a lot of time cooking can increase the risk of accidents connected to the stove.

Low incomes among residents mean that the choices in the housing market are limited and that there is a concentration of low-income earners in certain residential areas, preferably with rental apartments. This in combination with the fact that many with low incomes have a foreign background leads to ethnically segregated areas where fewer residents speaks the official language of the country. However, not speaking the official language of the country does not have to be a barrier to fire safety in homes in these areas, especially if information about fire safety is available in different languages. But it can lead to fire prevention not being given priority because of e.g. stressful living conditions, experiences from previous types of housing (informal and formal), or varying trust in authorities.

\subsection{Geo-statistical approach on residential fires}

In a socially fragmented city, the underlying determining factors often are unevenly spatially distributed. In order to determine the extent to which they affect the occurrence of different types of residential fires in different residential areas, statistical analyses need to be carried out. In addition, residential fires need to be analyses and 
mapped in GIS in different ways to show how they vary within and between cities. Later in the chapter, a GIS-based approach is applied on the city of Gothenburg in Sweden as an example. The purpose of the geo-statistical approach is to show possible socio-spatial differences but also to develop proactive proposals on how to work fire prevention in different residential areas.

\subsection{Types of residential fires}

Residential fires can be categorized in several ways, for example by fire ignition or fire losses, or by human or non-human action [38-40]. In this study, the residential fires registered by the rescue services in Swedish metropolitan areas are classified into three main groups or types depending on their causes [22].

1. Intentional fires can be seen as an expression of norm-breaking behaviors or mental illness. The intentional act of setting things on fire can be related to a conflict or to hide other crimes. In many cases there are other motives behind, such as thrill seeking, boredom, or serious play with fire [35]. Intentional fires in buildings often takes place in common areas in apartment buildings, e.g. stairwells, basements and attics [41].

2. Unintentional (accidental) fires due to human behavior can occur due to various activities and where the ability to prevent, detect and prevent them is insufficient. Stress, forgetfulness, inattention, disability, decreased level of consciousness due to intake of alcohol, drugs or medication, or accidents can lead to fire incidents [27]. Common causes or activities are cooking, smoking, using candles, etc.

3. Residential fires caused by technical errors, e.g. electrical faults, work processes or other causes can occur as a result of defects in technical equipment or neglected maintenance. They can also take place during maintenance work in a residential building or be related to the heating system such as chimney fires [42]. Residential fires with other causes are also fires where the rescue services cannot determine the underlying causes. Residential fires that occur because of children playing with fire or fireworks have also been placed in this category. Children's play with fire can be said to be a form of intentional fire but which cannot be directly linked to pronounced motives and can moreover be due to trillseeking, ignorance of the individual and lack of control from adults [36]. The categories of other and unknown fires are treated overall in this context and not as specific types of residential fire in the geographical reporting and analysis below. 


\subsection{Modeling of causes of residential fires}

Although it is possible to demonstrate statistical correlations between the occurrence of different types of residential fires and the underlying determining factors, it is not the same as having a causal relationship. As an intermediary, different hypothetical arguments can be applied and tested to highligt the dynamics between direct and indirect determining factors. Following hypotheses exemplify possible causal links between different types of fires and underlying determining factors. The hypotheses are also spatially valid in that they can be linked to residential areas with specific socio-economic and demographic conditions. [22].

Hypothesis 1: Inattention and forgetfulness lead to an increased risk of fire in a home. Unintentional residential fires can affect most people. Fire incidents are most often handled by household members and rarely require support form rescue services. There should be an overrepresentation in residential areas with many single elderly people (reduced mobility) or young people living alone (outdoor life and alcohol).

Hypothesis 2: Abuse of alcohol and drugs, mental illness or disability leads to an increased risk of fire in the home. These accidental fires can affect most people but above all risk groups. Fire incidents are handled less often by the individual and usually give rise to operations from the rescue service. There should be an overrepresentation in residential areas with many people with risk behaviors, e.g. people with substance abuse, mental illness, physical disability and people who over fill their homes with things (so-called collectors). In this group, there is a higher risk of fatal fires.

Hypothesis 3: Overcrowding, specific cooking habits and difficulties in assimilating information in the prevailing language can lead to an increased risk of fire in the home. This applies to residential fires that occur in living environments where people live crowded and use a lot of oil in their cooking. Fire incidents can be handled by residents but often require operations from the rescue service. There should be an overrepresentation in residential areas where many families have a foreign background, live cramped in their homes, and use a lot of oil in their cooking.

Hypothesis 4: Behaviors that lead to an increased risk of intentional fire setting in and around residential buildings. This type applies to residential fires that occur in residential areas with low social control and many young people with normbreaking behaviors or where there are people with mental illness. In most cases, intentional fires occurs in common areas such as basements, laundry rooms, garbage rooms and attics. Intentional fires usually cause a rescue service operation. There should be an overrepresentation of this type of residential fires in residential areas with unstable family conditions, overcrowding, neglected care and maintenance.

The analysis examples below relate only to a limited extent to how these hypotheses can be applied, but they can, based on previous research results $[22,43]$, work as a point of departure for further analyses of residential fires in metropolitan areas. 
The hypotheses are particularly important in the area-based fire prevention work, which is exemplified at the end of this chapter.

\section{Data and Methods}

This section presents the datasets and methods used in this chapter. There are also references to more detailed descriptions in previous research.

\subsection{Data}

The dataset used in this chapter has its origin in several Swedish agencies and organizations. The statistical dataset on residential fire incidents and socio-economics from 2007-2015 is based on 853 subareas from 16 municipalities and 5 different Emergency services in Sweden covering the three largest metropolitan areas in Sweden [44].

The fire dataset provided by the Emergency Services Gothenburg over the city of Gothenburg consist of 2797 residential fire incidents from 2007 to 2015. The dataset includes positions (X-and Y-coordinates) of residential fire incidents as well as a diversity of information about assessed causes of fire, addresses, starting places and starting times of fires. Residential data and additional geodata are collected from the city of Gothenburg and Statistics Sweden. ESRI's basemap Human geography Map (without labels) is used as background.

\subsection{GIS and statistics}

In this chapter, the statistical approach in section 4.2 is based on an indexation (social index) of the variables education level, employment rate and disposable average income. In previous studies, these variables have been linked to analyses and explanations of differences in living conditions between different areas within and between cities [7,37]. These variables have also been shown to correlate with residential fires in various major Swedish cities [44].

Different methods for geovisualisation - point data, kernel density and choropleth mapping - have been applied to increase the possibility for spatial analysis of residential fires (section 4.3). Earlier studies shows that each method itself has limitations regarding analytical depth and visualisation of fires, but that, in combination, they can improve the possibilities of targeting different forms of area-based fire preventive measures [5]. The kernel density map is combined with a map layer 
over living conditions, which is an indexation based on eight socio-economic and demographic variables from 2016-2018. This index has been applied in previous research in order to analyse the geo-statistical relationship between living conditions and crime $[37,45]$. The index is based on the variables marital status (single parents), number of children between ages of 0-15, number of adolescents between the ages of 16-19, population per square kilometer, descent, employment rate and income. Many of these variables have been presented above as indirect determinants of residential fires. Populated areas in Gothenburg are mapped in $250 \times 250$ meter grids.

\subsection{Study area}

In this chapter, the GIS-based visualisations of residential fire data are demonstrated using the municipality of Gothenburg as an example. Gothenburg is the second largest city in Sweden, with more than 1300 inhabitants per $\mathrm{km}^{2}$. The municipality have about 582,500 inhabitants (2020) and more than 286,000 residences. Over $81 \%$ of the residences are rented or co-operative apartments in apartment buildings [46]. The city of Gothenburg is characterized by a social, economic and spatial division spread over a large surface $\left(447.76 \mathrm{~km}^{2}\right)$. Between 2008-2020, the population has increased by over 7,000 people per year, a total of over 86,000 inhabitants for these years [46]. This continuous influx of new residents, especially to apartment buildings, has probably contributed to increasing the number of reported residential fires in the city.

\section{Residential fires and living conditions}

This section addresses how residential fire incidents in different (Swedish) metropolitan areas have developed between the years 2007-2017. The section also exemplifies how different GIS-based methods can be applied effectively to present, analyse and help explain the spatial patterns of residential fires in the city of Gothenburg. In the section, the geo-statistical relationship between different types of residential fires and underlying indexed determining factors/living conditions is presented and analysed more deeply. 


\subsection{Fire statistics in Sweden and Gothenburg}

The number of interventions from the rescue services to residential fires has gradually decreased in Sweden 2007-2017 (fig. 3-2.1). Differences between major cities are particularly interesting. The average number of residential fires per inhabitant the year of 2008 differ by a factor of two between the highest and lowest value. Not least, the differences between Stockholm, Gothenburg and Malmö (Emergency Services South) are unanticipated (fig. 3-2.1).The differences between the cities are much lower in 2017. Even within these metropolitan areas, there are large differences. A study from 2013 on outdoor fires 2007-2013 in Malmö identified clear concentrations in socio-economically vulnerable areas. In several of these areas, there was also a high concentration of residential fires [11,35].

Statistics on residential fires from 2007-2017 shows an upward trend for the city of Gothenburg, which goes from 0.59 residential fires per 1,000 inhabitants in 2007 to 0.77 in 2017 . As shown in figure 3-2.1, Gothenburg also goes from having lower average than all of Sweden and the other metropolitan areas of Malmö and Stockholm in 2007, to increase above the national average in 2017 . The main reason for the upward trend is a slightly increase of unintentional residential fires from 2007 2017. Gothenburg City is the largest out of five municipalities within the Emergency Services Gothenburg's geographical district of responsibility.

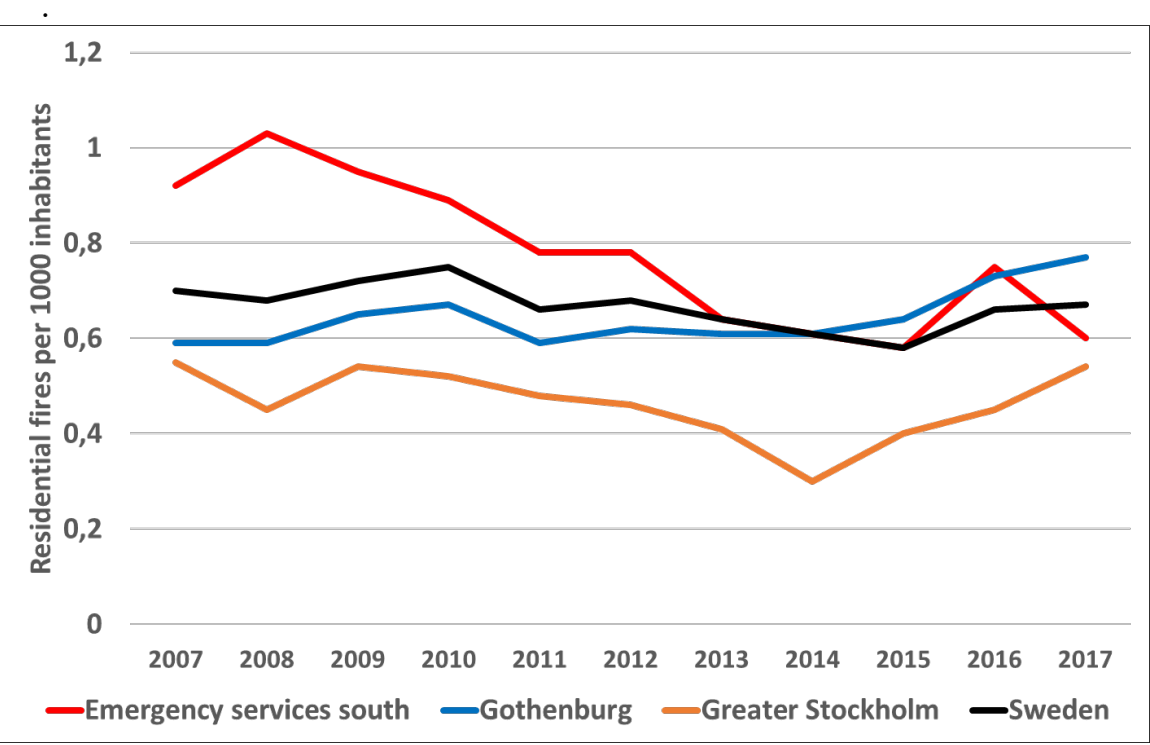

Fig. 3-2.1 Residential fires per 1,000 inhabitants in four emergency services organizations in Sweden 2007-2017 


\subsection{Statistical relationship - living conditions and residential fires}

Figure 3-2.2 shows the relationship between living conditions and the occurrence of house fires in 853 subareas from three metropolitan areas divided into six groups. These groups have been ranked after level of living conditions and frequency of residential fires. A chi ${ }^{2}$ test verifies a significant relationship between the categories [44]. The social index goes from very exposed to good living conditions, from left to right. Subareas with the most exposed living conditions (the bar on the far left) have a much higher number of residential fires per 1,000 inhabitants than those with the most advantageous living conditions (the bar on the far right). The number of residential fires that give rise to rescue service operations are four times higher in areas with the most exposed living conditions than in areas with the good living conditions. The bar on the left also shows an exceptional high number of residential fires. There are more unintentional and intentional, and unknown/other residential fires compared to other groups. This indicate that a large part of the rescue operations are carried out in densely populated areas with poorer living conditions, and where there are many apartment buildings.

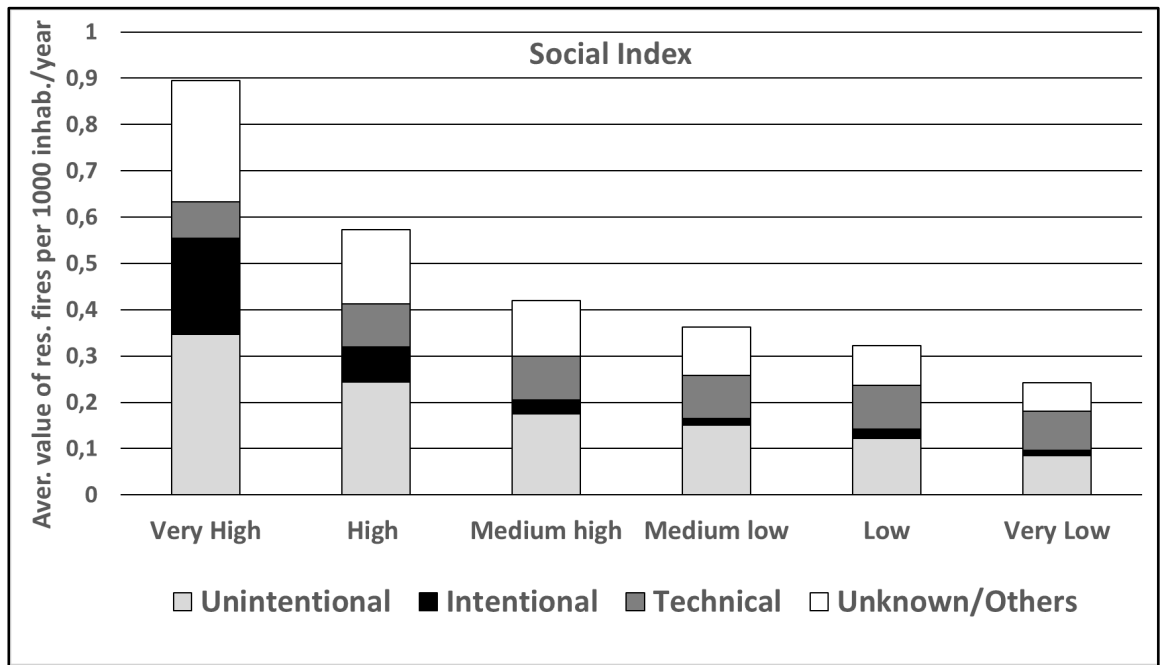

Fig. 3-2.2 Number of fires per 1,000 inhabitants by social index class

Living conditions are thus of great importance for the number and type of residential fires that causes rescue service operations, which is also shown in the GIS analysis in section 4.3. In residential areas with very exposed living conditions, the probability of a residential fire incident is four times as high compared with those areas with very good living conditions. There is also a significantly higher risk that the 
incident has developed into a fire. On the other hand, the probability that the residential fire is unintentional or has an unknown reason is approximately equal in all types of residential areas. In residential areas with better living conditions, the proportion of fires caused by technical faults, including chimney fires and soot fires, is higher. An explanation is that in these areas there are more villas and detached houses.

There seems to be a spatial and statistical correlation between different living conditions and residential fire incidents that lead to rescue service operations. An indicator of this is that many intentional fires appear to occur in socially exposed residential areas [11,41]. A second possible explanation lies in the already introduced concepts of Fire Risk Environment and Fire Protection Capability. Different individual, social and technical conditions in residents may affect the probability of a fire incident to occur. However, some studies indicate that fire risk environments may not differ between households, and that fire incidents occur at least as often in households with high average incomes [25]. A possible explanation is that residents' Fire Protection Capability is higher in residential areas with good living conditions. If these citizens handle many of their own fire incidents, the rescue service is not alerted, nor is an event report written. This is also consistent with studies that show that households have more fires than can be seen in the statistics [47]. A hypothesis based on this reasoning is therefore that households and residential areas with poorer living conditions have lower Fire Protection Capability. Another hypothesis is that residents in apartment buildings more often call the emergency center.

\subsection{Geographical distribution of residential fires in Gothenburg}

Figures 3-2.3 and 3-2.4 show all residential fires in Gothenburg between 2007 and 2015 as well as living conditions. In map 1 in figure $3-2.3$, there are 2,797 coordinated residential fires. This map gives an overall representation of residential fire incidents in Gothenburg.

Map 2 in figure 3-2.3 presents residential fires per 1,000 inhabitants and year distributed over subareas in Gothenburg. The average value for mapped subareas in Gothenburg is 0.60 residential fires per 1,000 inhabitants and year. This is lower than, e.g. the City of Malmö (0.88), but higher than the average for Sweden's metropolitan areas (0.49). In Gothenburg, Hammarkullen has the highest value with 1.86 residential fires per 1,000 inhabitants and year. Other subareas with higher values than the average are Östra Bergsjön, Frölunda Torg, Rannebergen, Västra Bergsjön, Rambergsstaden, Hjällbo, Södra Biskopsgården and Högsbotorp.

The surface-based cluster map 3 in figure 3-2.4 of residential fires coincide to a large extent with population-normalized map 2 in figure 3-2.3 over Gothenburg's populated areas. The strongest surface-cluster is again to be found in Hammarkullen with 314 residential fires per $\mathrm{km}^{2}$. Some other subareas with high concentrations of 
residential fires are Hjällbo and Rannebergen, Östra and Västra Bergsjön, Norra and Södra biskopsgården, Kyrkbyn, Rambergstaden and Frölunda torg.

Map 4 combines the most clustered fire areas with living conditions. As can be seen in the map, there are strong concentrations of residential fires in several areas with very exposed living conditions, mainly in in relatively fire dense areas such as Hammarkullen Hjälbo, Biskopsgården, Östra and Västra Bergsjöns and Västra Frölunda. This result states that spatial clusters of residential fires is probably related to social and demographic causes. The types of residential fires that dominate areas with exposed living conditions are both intentional and unintentional, but also fires with unknown causes (see sections 2.4 and 4.1). There are also concentrations of residential fires in other parts of Gothenburg, e.g. in the city center where living conditions are normally good. This pattern is expected because the population density, which is a fundamental determinant to residential fires, is usually high in central urban environments. A dominant type of residential fires in urban areas with good living conditions are accidental fires, and with the kitchen as the most common starting point for the fire [41].



Fig. 3-2.3 Positions of residential fires and residential fires per 1,000 inhabitants and year 2007-2015 


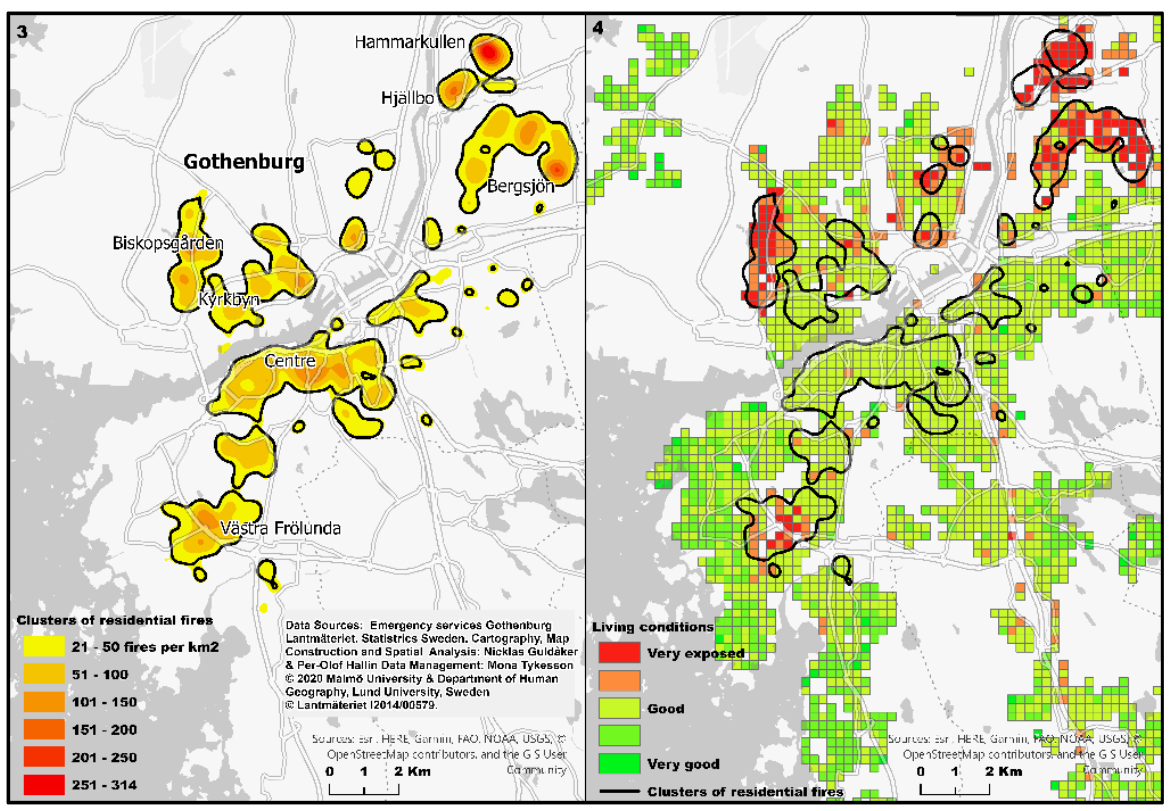

Fig. 3-2.4 Clusters of residential fires and living conditions in Gothenburg

\section{Prevention of residential fires}

This last section addresses how an area-based systematic fire prevention work in metropolitan environments can be carried out and evaluated within an emergency service organization.

\subsection{Area-based and systematic fire prevention work}

Research results from the multi-year study on residential fires in Swedish metropolitan cities show that both general and specific measures are implemented to reduce the number of residential fires and limit the consequences of these fires when they occur. In order for the rescue services to reach different target groups, physical objects and residential areas, different types of activities are conducted, such as home visits, targeted campaigns, supervision and fire security-creating projects [43]. Studies from Canada and the UK show that several of these preventive activities can help reduce the number of fires over time [18]. As the Swedish multi-year study also shows, conditions may vary in different residential areas, and there are large 
differences regarding the type of residential fire that occurs, and the number of residential fires that give rise to rescue service operations [41]. As stated earlier in this chapter, differences in spatial residential fire patterns can be explained by a variation of living conditions over an urban area [44]. Various individual, structural, building-based and area-based factors affect residents' fire protection capability and residents can be seen as fire risk environments [22]. Thus, the conditions may look different depending on the residential area, building stock, housing conditions and socio-economic conditions, and therefore, preventive strategies and preventive measures must differ $[10,18]$.

The proposed working method for area-based and systematic fire prevention work takes spatial variations of fires into account, and includes activities such as fire prevention work for both general and specific target groups, selection of areas, creation of area profiles, area analyses, creation of an action plan and evaluation.

Fire prevention strategies can be aimed at the entire population, certain risk groups, building types or in residential area where there is an increased probability of fire. Important activities are information campaigns, home visits, and personalized fire prevention. Collaboration between the rescue service, social services and the municipality is important for identifying residents, risk individuals and groups with special fire protection needs.

Starting points for selection of areas should relate to statistics and time series on residential fire data and socio-economic data [44]. To support this selection process, the GIS-based methods, analyses and map visualisations presented above can be applied [41].

Area profiles can help understand underlying trends and causes of residential fires. Such a profile should include fire development over time, different types of fire, causes of fire, starting points for fires and socio-economic data. Figure 3-2.5 presents an area profile for two subareas within Emergency Services Gothenburg.

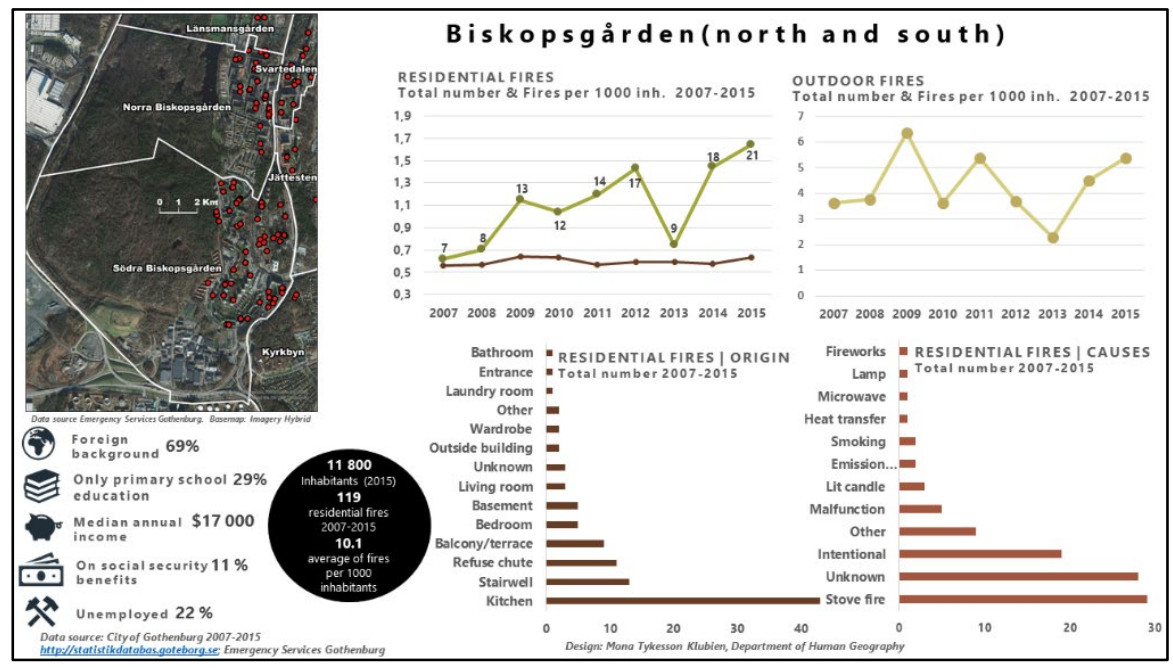


Fig. 3-2.5 Example of area profile of the subareas: Norra (Northern) and Södra (Southern) Biskopsgården in Gothenburg

In the area analysis, it is clear that the variety of information over time and space provides the rescue services with additional support in selecting areas as well as establishing different strategies for more targeted fire safety work to different areas. Depending on available resources, hypotheses and statistical analyses can be performed and tested. In the area example in figure 3-2.5, residential fires in kitchens in apartment buildings seem to be a problem. It is clear that many fire incidents in these two subareas start during cooking. In this context, the hypothesis about overrepresentation of many families having a foreign background, live cramped in their homes, and using a lot of oil in their cooking seems appropriate to test and evaluate (see section 2.5). The Northern and Southern Biskopsgården have also had problems with intentional fire setting related to criminal activities, riots and other forms of social unrest during the period 2007-2015 [48]. Here, hypothesis 4 on overrepresentation of this type of residential fires in residential areas with unstable family conditions, overcrowding, neglected care and maintenance should also be tested and evaluated.

The action plan is thus based on geographical patterns, area profiles and the causal analysis. The plan also describes the preventive activities that need to be implemented in the residential areas. In the case of Northern and Southern Biskopsgården, preventive measures in order to try to reduce the number of kitchen fires and intentional fires are priority. There are several challenges for the emergency services, including trying to reach a heterogeneous and multilingual population, and cooperating with other societal key actors, such as the police, municipality social services, property owners, schools, security companies and leisure centers, etc.

The evaluation should be carried out in accordance with the action plan. This can be done by assessing expected effects in the short and long term, as well as assessing the outcomes. Insurance companies may also be important actors in this process. Furthermore, it is important that the fire prevention work is well documented in a digital operating system, and that the rescue service's organization and members receives clear feedback. An emergency service organization should also preserve special functions that work with learning and evaluation of the fire prevention work. This work should also take into account key aspects such as social sustainability, diversity, gender equality, behaviors and attitudes. 


\section{References}

1. Corcoran J, Higgs G, Higginson A (2011) Fire incidence in metropolitan areas: A comparative study of Brisbane (Australia) and Cardiff (United Kingdom). Applied Geography 31 (1):65-75. doi:10.1016/j.apgeog.2010.02.003 2. Kiran K, Corcoran J (2017) Modelling residential fire incident response times: A spatial analytic approach. Applied Geography 84:64-74. doi:10.1016/j.apgeog.2017.03.004

3. Yang C-H, 楊奇樺 The Study of Spatial and Temporal Distribution of Fire Events in Tainan City from 2004 to 2013. 臺南市2004至2013年火災案件時空分 佈之研究.

4. Špatenková O, Virrantaus K (2013) Discovering spatio-temporal relationships in the distribution of building fires. Fire Safety Journal 62 (Part A):49-63. doi:10.1016/j.firesaf.2013.07.001

5. Guldåker N (2020) Geovisualization and Geographical Analysis for Fire Prevention. ISPRS International Journal of Geo-Information 9 (355):355-355. doi:10.3390/ijgi9060355

6. Martín-Gómez C, Vergara-Falces J, Elvira-Zalduegui A (2015) Geographic information system software application developed by a regional emergency agency. Case Studies in Fire Safety 4:19-27. doi:DOI: 10.1016/j.csfs.2015.06.002. 7. Guldåker N, Hallin P-O, Nilsson J, Tykesson M (2018) Bostadsbränder i storstadsområden. MSB1171 edn. Myndigheten för samhällsskydd och beredskap, Karlstad

8. Taylor M, Higgins E, Lisboa P (2012) Testing geographical information systems: a case study in a fire prevention support system. Journal of Systems \& Information Technology 14 (3):184. doi:10.1108/13287261211255310

9. Asgary A, Ghaffari A, Levy J (2010) Spatial and temporal analyses of structural fire incidents and their causes: A case of Toronto, Canada. Fire Safety Journal 45 (1):44-57. doi:10.1016/j.firesaf.2009.10.002

10. Jennings CR (1998) Urban Fire Risk: Using GIS to Connect Fire, Census, and Assessor's Data. Regional Science Review 17:105-112.

11. Guldåker N, Hallin P-O (2014) Spatio-temporal patterns of intentional fires, social stress and socio-economic determinants: A case study of Malmö, Sweden. Fire Safety Journal 70:71-80. doi:10.1016/j.firesaf.2014.08.015

12. Higgins E, Taylor M, Jones M, Lisboa PJG (2013) Understanding community fire risk-A spatial model for targeting fire prevention activities. Fire Safety Journal 62 (Part A):20-29. doi:10.1016/j.firesaf.2013.02.006 13. Taylor M, Higgins E, Lisboa P, Jarman I, Hussain A (2016) Community fire prevention via population segmentation modelling. Community Development Journal 51 (2):229-247. doi:10.1093/cdj/bsv006

14. Krisp JM, Virrantaus K, Jolma A (2005) Using Explorative Spatial Analysis to Improve Fire and Rescue Services. In: Oosterom P, Zlatanova S, Fendel EM (eds) 
Geo-information for Disaster Management. Springer, Berlin, Germany, pp 12831296. doi:10.1007/3-540-27468-5_89

15. Wuschke K, Clare J, Garis L (2013) Temporal and geographic clustering of residential structure fires: A theoretical platform for targeted fire prevention. Fire Safety Journal 62 (Part A):3-12. doi:10.1016/j.firesaf.2013.07.003

16. Zhang X, Yao J, Jin Y, Sila-Nowicka K (2020) Urban fire dynamics and its association with urban growth: Evidence from Nanjing, China. ISPRS International Journal of Geo-Information 9 (4). doi:10.3390/ijgi9040218 17. Ferreira TM, Vicente R, Raimundo Mendes da Silva JA, Varum H, Costa A, Maio R (2016) Urban fire risk: Evaluation and emergency planning. Journal of Cultural Heritage 20:739-745. doi:10.1016/j.culher.2016.01.011

18. Thomas L, Garis L, Morris S, Biantoro C (2020) Journey of HomeSafe: Community Risk Reduction in Surrey Analyses from Surrey Historical Data. Surrey Fire services and University of the Fraser Valley, British Columbia, Canada.

19. MacEachren AM, Gahegan M, Pike W (2004) Visualization for constructing and sharing geo-scientific concepts. Proceedings of the National Academy of Sciences of the United States of America 101:5279. doi:10.1073/pnas.0307755101 20. MacEachren AM, Gahegan M, Pike W, Brewer I, Cai G, Lengerich E, Hardistry F (2004) Geovisualization for knowledge construction and decision support. IEEE Computer Graphics and Applications, Computer Graphics and Applications, IEEE, IEEE Comput Grap Appl 24 (1):13-17. doi:10.1109/MCG.2004.1255801

21. Tykesson Klubien M, Nilsson J, Guldåker N, Hallin P-O (2018)

Bostadsbränder i storstadsområden - Kvalitetsgranskning av insatsrapportering av bostadsbränder - Storstadsområdena Malmö, Göteborg, Södertörn och Stockholm. Department of Human Geography, Lund University. Urban studies, Malmö University. doi:10.13140/RG.2.2.14809.67687

22. Hallin P-O, Guldåker N, Nilsson J, Tykesson Klubien M (2018)

Bostadsbränder i storstadsområden - teoretiska utgångspunkter. Department of Human Geography, Lund University. Urban studies, Malmö University. doi:10.13140/RG.2.2.13736.11527

23. Barnett M, Bruck D, Jago A (2007) Mean Annual Probability Of Having A Residential Fire Experience Throughout A Lifetime: Development And Application Of A Methodology. Melbourne, Australia 24. Hallin P-O, Andersson R, Andersson P (2018) Brand i bostäder - så ska färre skadas och dö. Myndigheten för samhällsskydd och beredskap (MSB) och Brandforsk, Karlstad

25. Nilson F, Bonander C, Jonsson A (2015) Differences in Determinants Amongst Individuals Reporting Residential Fires in Sweden: Results from a Cross-Sectional Study. Fire Technology 51 (3):615-626. doi:10.1007/s10694-0150459-0 
26. Nilson F, Bonander C (2020) Household Fire Protection Practices in Relation to Socio-demographic Characteristics: Evidence from a Swedish National Survey. Fire Technology 56 (3):1077-1098. doi:10.1007/s10694-019-00921-w 27. Kobes M, Post JG, Helsloot I, de Vries B (2010) Building safety and human behaviour in fire: A literature review. Fire Safety Journal 45 (1):1-11. doi:10.1016/j.firesaf.2009.08.005 28. Jennings CR (2013) Social and economic characteristics as determinants of residential fire risk in urban neighborhoods: A review of the literature. Fire Safety Journal 62 (Part A):13-19. doi:10.1016/j.firesaf.2013.07.002

29. Taylor MJ, Higgins E, Lisboa PJG, Kwasnica V (2012) An exploration of causal factors in unintentional dwelling fires. Risk Management (14603799) 14 (2):109. doi:10.1057/rm.2011.9

30. Jonsson A, Jaldell H (2020) Identifying sociodemographic risk factors associated with residential fire fatalities: a matched case control study. Inj Prev 26 (2):147-152. doi:10.1136/injuryprev-2018-043062

31. Špatenková O, Stein A (2010) Identifying factors of influence in the spatial distribution of domestic fires. International Journal of Geographical Information Science 24 (6):841-858. doi:10.1080/13658810903143634

32. Jonsson A, Bonander C, Nilson F, Huss F (2017) The state of the residential fire fatality problem in Sweden: Epidemiology, risk factors, and event typologies. J Safety Res 62:89-100. doi:10.1016/j.jsr.2017.06.008

33. Biggs JB, Tang CS-k, Society for Research into Higher E (2011) Teaching for Quality Learning at University: What the Student Does, vol 4th ed. McGraw-Hill Education, Maidenhead

34. Goodsman RW, Mason F, Blythe A (1987) Housing factors and fires in two metropolitan boroughs. Fire Safety Journal 12 (1):37-50. doi:10.1016/03797112(87)90014-2

35. Guldåker N, Hallin P-O (2013) Standens Bränder Del 1 - Anlagda bränder och Malmös sociala geografi. Malmö University publications in urban studies (MAPIUS) 9. Malmö University, Malmö

36. Lindgren S-Å, Björk, M, Ekbrand, H, Persson, S, Uhnoo, S. (2013)

Barn/ungdomar som anlägger brand - orsaker och motåtgärder - Slutrapport. The Department of Sociology and Work Science, University of Gothenburg 37. Hallin P-O, Westerdahl, S (2020) Utsatta livsvillkor. In: Gerell M, Hallin, P$\mathrm{O}$, Nilvall, K., Westerdahl, S (ed) Att vända utvecklingen: från utsatta områden till trygghet och delaktighet. Malmö University publications in urban studies (MAPIUS) 26. Malmö University, Malmö, pp 24-40

38. FEMA (1997) Socioeconomic factors and the incidence of fire. Federal Emergency Management Agency United States Fire Administration National Fire Data Center (U.S.)

39. Higgins E, Taylor M, Francis H, Jones M, Appleton D (2015) Transforming fire prevention: a case study. Transforming Government 9 (2):223. doi:10.1108/TG-05-2014-0017 
40. Taylor M, Higgins E, Francis M, Lisboa P (2011) Managing unintentional dwelling fire risk. Journal of Risk Research 14 (10):1207-1218.

doi:10.1080/13669877.2011.587884

41. Guldåker N, Tykesson Klubien M, Hallin P-O, Nilsson J (2018) Rumsliga skillnader i den socialt fragmenterade staden. Department of Human Geography, Lund University and department of Urban Studies, Malmö University. doi:10.13140/RG.2.2.24876.00649

42. Bengtsson L-G (2013) Inomhusbrand., vol MSB595. 4 edn. Myndigheten för samhällsskydd och beredskap, Karlstad

43. Guldåker N, Hallin P-O, Tykesson Klubien M, Nilsson J (2018)

Brandsäkerhetsarbete i den socialt fragmenterade staden. Department of Human Geography, Lund University. Urban studies, Malmö University.

doi:10.13140/RG.2.2.13011.94241

44. Nilsson J, Hallin P-O, Tykesson Klubien M, Guldåker N (2018) Skillnader i brandförekomst inom och mellan olika storstadsområden - en statistisk analys.

Department of Human Geography, Lund University. Urban studies, Malmö University. doi:10.13140/RG.2.2.23399.39846

45. Guldåker N, Hallin P-O (2020) Livsvillkor och strategisk lägesbild. In: Gerell M H, P-O, Nilvall, K., Westerdahl, S (ed) Att vända utvecklingen - Från utsatta områden till trygghet och delaktighet, vol 26. Malmö University publications in urban studies (MAPIUS) 26. Malmö University, Malmö, pp 181-188

46. Göteborgs Stad Statistik och analys. (2020) Available via Göteborgs stad. Göteborgs Stad https://goteborg.se/wps/portal/enhetssida/statistik-ochanalys/demografi-och-analys/korta-kommentarer/befolkningsutveckling20192?uri=gbglnk\%3A20200302112859772. Accessed 2021-01-04 2021 47. Sandqvist A, Holmberg, H. (1997) Vill du bidra till ett säkrare samhälle? resultat från en undersökning om bränder och brandskydd i hemmet. Statistiska centralbyrån $(\mathrm{SCB})$.

48. Weirup L (2020) Gangsterparadiset: Så blev Sverige arena för gängkriminalitet, skjutningar och sprängdåd. Bokförlaget Forum, Stockholm 